\title{
Da de danske præster i Slogs herred blev fordrevet
}

\author{
Af Henning Heilesen.
}

Ved udrensningen efter Treårskrigen blev de gamle tyskuddannede og tysksindede præster siddende i 3 af Slogs herreds 6 sogne, nemlig pastor Hoeck i Hostrup, pastor Beyer i Tinglev og pastor Meyer i Rabsted. I Højst sogn, der var ledigt siden pastor Bjørnsens død i oktober 1849, blev Sabinus Høxbroe konstitueret som sognepræst i juni 1850 og udnævnt efter menighedens begæring $i$ september samme år. ${ }^{1}$ Han var født 1819 i Rodding som søn af amtsprovst Hans Høxbroe og dennes 2. hustru, Karen Chrisline f. Arntzen, en præstedatter fra Sønder Vissing ved Skanderborg. Da han var 9 år gammel, døde hans fader, hvorefter moderen flyttede til Ribe. Derfra blev han student 1838. Efter at han 1844 var blevet teologisk kandidat, var han først kapellan hos sin morfader i Sønder Vissing; efter morfaderens død i efteråret 1846 var han kapellan i Todbjerg ved Århus, indtil han kom til Højst. Ca. 1860 begyndte han at skrive sig Høgsbro ligesom sin 3 år yngre broder, højskolemanden og politikeren Sofus Høgsbro. ${ }^{2}$ Som præst i Højst var han meget agtet af sin menighed.

Pastor P. C. Schmidt i Burkal, som oprørsregeringen havde forflyttet dertil fra Bylderup i 1849, blev i december 1850 forflyttet til Skodborg.' I stedet for ham blev Johannes Georg Elias Koch valgt til præst i Burkal i maj 1851. Han var født 1821 på Ledreborg, hvor hans fader, som stammede fra Kassel, var gartner." I sin studentertid i København 1841-46 blev han en trofast discipel af den senere biskop Martensen, som da var professor ved Københavns universitet. Efter sin embedseksamen var han en tid kapellan ved Vor Frue kirke i Arhus og var derefter lærer ved den videnskabelige realskole sammesteds, indtil han kom til Burkal. Oprindelig blev han modtaget med uvilje af de større gårdmænd i 
sognet, som hovedsagelig var tysksindede, men han vandt anseelse ved sine prædikener og bibellæsninger. Han blev særlig kendt ved sine undersøgelser over folkesproget i Sønderjylland. Resultaterne af disse undersøgelser of fentliggjorde han $i$ artiklen $\rightarrow$ Den mellemslesvigske Slette og dens Beboere" i 1. hæfte af "Slesvigske Provindsialefterretninger" (1858) og i "Det danske Folkesprog $\mathrm{i}$ Sønderjylland «, hvis 1 . bind udkom 1863. På titelbladet til sidstnævnte skrev han for første gang sit efternavn Kok."

Til pastor Schmidts efterfølger i Bylderup havde oprørsregeringen udnævnt cand. theol. Andreas Matzen, som stammede fra Dyrhus ved Tønder. Denne udnævnelse blev kasseret sidst $i$ august 1850, men Matzen blev samtidig konstitueret i embedet og blev $i$ Bylderup til april 1851, da han blev kst. sogneprest i Frederiksstad. Her blev han, til han i $\mathbf{1 8 5 4}$ blev præst i Trelstorp ved Bredsted. Til Matzens efterfølger som præst i Bylderup valgtes i marts 1851 Holten Frederik Lützhøft. ${ }^{7}$ Han var af gammel angelboslægt; hans farfader stammede fra Sønder Brarup i Angel. Hans fader var oprindelig prokurator i Frederikssund, hvor han selv blev født 1822; senere var han en tid lang godsforvalter på Algestrup og Egemarke i Nordvestsjælland og var sidst prokurator $i$ Kalundborg. Lützhøft blev student fra Vordingborg $1840 \mathrm{og}$ cand. theol. 1846. Efter sin embedseksamen foretog han en rejse til Tyskland og besøgte universiteterne i Berlin, Halle og Leipzig. Han hørte også forelæsninger i Lund. Fra 1847 var han lærer ved søetatens drengeskole, hvor han 1848 blev overlærer. I modsætning til Høxbroe og Koch havde han ikke haft nogen præstegerning, før han kom til Slogts herred, men ligesom de vandt han sin menigheds agtelse. ${ }^{8}$

I november 1856 tog den 77årige pastor Hoeck i Hostrup sin afsked. Hans efterfølger, hvis valg blev stadfæstet i maj 1857, blev Maurits Mørch, hidtil præst i Rejsby.' Han var af nordjysk præste- og degneslægt, var selv præstesøn, født 1816 i Fjellerad i Gunderup sogn ved Ålborg, hvor hans fader da var kapellan. Hans fader var broder til Mourits Mørk Hansens moder. Senere blev faderen præst i Mosbjerg i Vendsyssel, hvor han døde 1832, året før sønnen blev student fra Allborg. Han blev cand. theol. 1838 og var derefter huslærer forskellige steder, indtil han i 1849 blev præst $\mathrm{i}$ Rejsby. 22. juli samme år blev han indsat $\mathrm{i}$ sit embede af 
provst Matzen. ${ }^{10}$ Knap 14 dage efter fik han at mærke, at der var krigstid og besættelse i Nordslesvig, idet den tidligere amtsforvalter Krogh i Haderslev vesteramt, der af oprørsregeringen var blevet indsat som politimester sammesteds, 4. august lod ham arrestere og senere transportere til kongeriget. ${ }^{11}$ En måneds tid senere var bestyrelseskommissionen trådt i virksomhed, og Mørch kunne vende tilbage til sit embede. ${ }^{12}$ Ved stændervalgene $i$ efterâret 1860 blev han valgt som suppleant i 3 . gejstlige valgdistrikt (for pastor Christiansen i Medelby) og deltog 13. februar 1861 i de dansksindede stænderdeputeredes og suppleanters møde i Flensborg. Her var han med til at vedtage en udtalelse om, at Slesvig onskede at forblive en uadskillig del af Danmarks rige og at udsondres yderligere fra alt fællesskab med Holsten. ${ }^{18}$

Da krigen 1864 udbrød, var der altså 4 danske præster i Slogs herred. Da den endte med freden i Wien, var der kun een tilbage. Hvordan det gik til, skal fortælles i det følgende.

Dengang preusserne og østrigerne besatte Sønderjylland, blev alle kirkevisitatorierne lidt efter lidt fortyskede. Alle amtmændene og næsten alle provsterne blev afskediget og erstattet af afgjort tysksindede mænd. I Tønder amt skete dette allerede i marts 1864, idet amtmand Brockenhuus-Schack og provst Hjort afskedigedes og afløstes af appellationsretsråd de Fontenay fra Kiel, hvis fader havde været husfoged i Tønder, og diakon Carstens i Tønder. Hjemmetyskerne i Slogs herred, som hidtil havde forholdt sig rolige ${ }^{14}$ vejrede nu morgenluft og gjorde skridt til at fordrive de danske præster. 29. marts 1864 skrev pastor Lützhøft i sin dagbog, at der af hjemmetyskerne var stillet den fordring til ham som til andre præster, at han skulle udstede dâbsattester for de slesvigske soldater i den danske hær, for at de, når de kom som fanger til Flensborg, kunne legitimere sig og desto mere fristes til at bryde deres Tro«. Denne fordring var også stillet til ham, men han havde nægtet den; så måtte det volde klage og afskedigelse, så meget det ville. ${ }^{15}$

Foreløbig var der dog ingen, som klagede til kirkevisitatoriet over Lützhøft. Det gjorde derimod nogle medlemmer af pastor Koks menighed over deres præst. 4. april modtog kirkevisitatoriet en klage fra Jürgen Th. Lorenzen og Hans Peter Hoeck, begge af Burkal sogn, over, at pastor Kok havde vægret sig ved på deres 


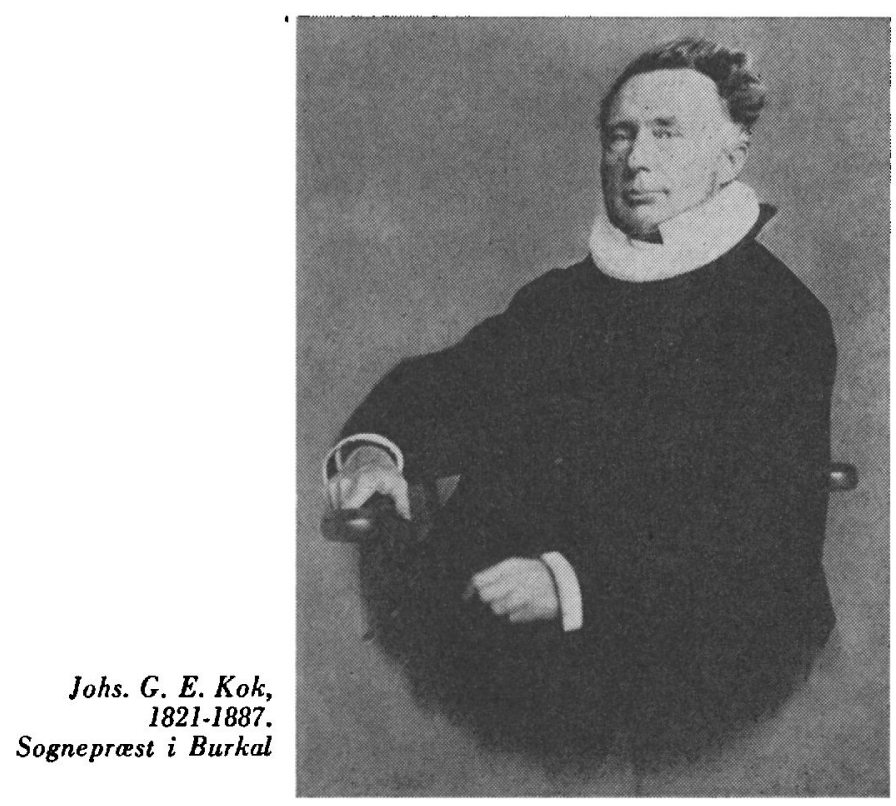

forlangende at udfærdige dábsattester for deres brødre Carsten Th. Lorenzen og Peter Christian Hoeck. ${ }^{10}$ Kirkevisitatoriet meddelte samme dag Kok, at han ikke blot straks skulle udlevere de onskede dåbsattester til de nævnte medlemmer af hans menighed, men at han fremtidig i lignende tilfælde ikke mátte nægte udfærdigelsen af dåbsattester på begæring af nærstående pårørende til de pågældende personer. ${ }^{17}$

Samme dag modtog kirkevisitatoriet en anonym skrivelse fra Burkal, hvori pastor Kok krævedes afskediget, samt en ansøgning til civilkommissærerne med samme krav. ${ }^{15}$ Denne skrivelse var skrevet af degnen i Burkal, Jørgen Andresen, ${ }^{19}$ men bag den stod vistnok den hjemmetyske leder i sognet, J. F. Momsen på Vrågârd, som i denne tid var meget aktiv for at få Kok afskediget. ${ }^{20}$ Han havde været stænderdeputeret, men var ved stændervalget 1860 til sin egen og sine meningsfællers ærgrelse blevet vraget $\mathbf{i}$ sin valgkreds til fordel for den dansksindede sognefoged Lund i Rørkær.

På grund af de nævnte klager blev Kok tilsagt til forhør hos kirkevisitatoriet 11. april. ${ }^{21}$ Han mødte og erklærede til at begynde 
med, at han onskede at tale dansk, da han ikke var det tyske sprog tilstrækkelig mægtig, men han havde ikke noget imod, at hans forklaring blev optaget på tysk i protokollen. Amtnand de Fontenay forhørte ham først om hans vægring ved at udstede dảbsattester for Jürgen Th. Lorenzens og Hans Peter Hoecks brødre. Kok forklarede, at han havde gjort andragerne opmærksom på, at udstedelsen af dåbsattesterne og deres fremsendelse til Flensborg let ville kunne bringe de to fangne soldater i mistanke om, at de var desertører; mod denne mistanke ville han beskytte dem, især da Peter Christian Hoeck før sin afrejse til hæren havde sagt til en bekendt, at han på ingen måde ville lade sig tage til fange. De to andragere havde derefter ikke mere insisteret på at få dåbsattesterne udstedt, men erklæret sig indforstået med præstens bemærkninger og var heller ikke senere kommet igen for at forlange attesterne. Kok bemærkede desuden, at en attest var et retsligt dokument, som ikke kunne udleveres til andre uden pá et myndigt menneskes eget forlangende; heri måtte amtmanden give Kok ret. ${ }^{\text {n }}$

Derefter udtalte amtmanden, at forskellige medlemmer af Koks menighed havde fremsat den klage, at de ikke var $i$ stand til at skænke deres præst den fornødne tiltro som deres sjælesørger, da han havde danske sympatier. Kok indrømmede, at han var dansk af sindelag og nærede danske sympatier, men hidtil var der ikke opstået nogen konflikt mellem hans embedsgerning og hans politiske indstilling. Han bad ikke for Christian IX, fordi det var forbudt, men i det stille gjorde han det. Man drøftede derefter forskellige af Koks udtalelser, bl. a. i sDet danske Folkesprog i Sunderjylland «, men Kok mente ikke, at de vedkom den underkastelseserklæring, han havde afgivet til civilkommissærerne. ${ }^{23}$ På amtmandens forespørgsel, om han havde $i$ sinde frivillig at søge sin afsked, svarede han, at han ikke agtede at gøre det, så læunge arvefølgespørgsmålet var uafgjort; han indrømmede dog, at som følge af de øjeblikkelige tidsomstændigheder var forholdet til hans menighed i mange henseender ikke, som det egentlig skulle være. Imidlertid tilføjede han, at en mand med modsatte anskuelser ville støde på tifold større vanskeligheder. Hidtil havde Carstens forholdt sig tavs, men nu fremsatte han den bemærkning, at Kok altid havde været konsekvent i sit standpunkt, og at han, Carstens, 
selv ogsà havdo været det. Denne belragtning kunne Kok ikke ga ind på, og da der blev talt om eden til Christian IX, som også Carstens havde aflagt, og denne mente, at det kom an på fortolkningen, udtalte Kok, at en ed var en ed, og enten brød man den, eller holdt man den; anden fortolkning kendte han ikke. Herefter havde Carstens ikke mere at sige, og denne for ham lidet smigrende diskussion kom ikke $i$ forhørsprotokollen. ${ }^{\text {s4 }}$ Amtmanden sluttede forhøret med at sige til Kok, at der ikke var megen rimelighed for, at han kunne beholde sit embede. Han kunne ikke love ham pension, men måske et par værelser til at hensætte sit tøj i i præstegârden. ${ }^{25}$

19. april sendte kirkevisitatoriet forhørsprotokollen til civilkommissærerne og indstillede samtidig Kok til afsked uden pension. I overensstemmelse med kirkevisitatoriets indstilling blev Kok afskediget 29. april og måtte allerede 8 . maj, på 13årsdagen for sit valg til præst i Burkal, forlade sin præstegård. Han rejste til København, hvor han i foråret 1865 var med til at stifte det såkaldte »slesvigske udvalg " sammen med bl. a. Mork Hansen. ${ }^{20}$ Han var her uden embede, indtil han 1867 blev præst ved Almindeligt Hospital. Fra 1872 til sin død 1887 var han præst ved Kastelskirken, hvor han blev kendt som en fremragende prædikant og ivrig deltager i teologiske debatter."

Den næste præst, hjemmetyskerne forsøgte at få afskediget, var Lützhøft, i første omgang dog uden held. 24. april sendte kirkevisitatoriet Lützhøft en skrivelse, at han var blevet anklaget for at have nægtet Peter Chr. Petersen i Bredevad en dåbsattest til hans broder i den danske hær. ${ }^{98}$ Anklagerens navn var ikke nævnt, men det var ikke Peter Chr. Petersen selv. Lützhøft modtog skrivelsen dagen efter; han henvendte sig samme dag til den på. gældende og fik af denne en skriftlig erklæring," at lige sã lidt som han selv havde klaget over pastor Lützhøft, lige så lidt havde han givet nogen $i$ opdrag at klage over hans adfærd mod ham; han (Lützhøft) var falsk anklaget, han havde ikke nægtet at udlevere hans broders dåbsattest. Denne erklæring sendte Lützhøft til kirkevisitatoriet med en følgeskrivelse, at det var vistnok ingen god sag for en anklaget at forsvare sig mod anonyme anklagere, men siden visitatoriet ikke gav ham til kende, hvem det var, som førte besværinger over ham, så måtte han jo tage sagen, som den 
forelagdes ham. Han havde henvendt sig til den pågældende gårdejer i Bredevad, den eneste, der havde en broder i den danske hær, og spurgt ham, om han havde ført nogen besværing over ham. Han tilbageviste spørgsmålet med indignation og gav Lützhøft den vedlagte erklæring, som sidstnævnte håbede, visitatoriet ville anse for bevis for, at hans anonyme anklager denne gang havde været fejl underrettet. Han tilføjede, at m. h. t. attester turde han ikke udlevere udskrifter af kirkebøgerne til myndige uden efter deres egen mundtlige og skriftlige rekvisition og til umyndige uden efter deres formynderes forlangende. Hvis han havde fejlet heri, udbad han sig nærmere instruks af kirkevisitatoriet.

3. maj svarede kirkevisitatoriet Lützhøft, at det var blevet godtgjort ved dennes og Peter Chr. Petersens skrivelser, at klagen mod ham var ubegrundet, og at klageren, der kun havde fremsat klagen mundtligt, ville blive draget til ansvar, såsnart han blev fundet. M. h. t. attesterne fik Lützhøft den besked, at under overordentlige omstændigheder, hvor den pågældendes egen mundtlige eller skriftlige rekvisition var umulig eller forbundet med betydelige vanskeligheder, havde han at meddele udskrifter af kirkebøgerne også på begæring af nære slægtninge. ${ }^{30}$

Efter at det var lykkedes hjemmetyskerne at få pastor Kok i Burkal afskediget, og de havde forsøgt at få pastor Lützhøft i Bylderup bort, kom nu turen til pastor Mørch i Hostrup. 31. maj mødte tre store hjemmetyskere i Hostrup sogn op på Tønder amtshus, nemlig B. B. Momsen på Store Tønde, som var broder til J. F. Momsen på Vrågård, J. L. Outzen på Solvig og M. B. Hostrup i Jejsing. ${ }^{\text {s1 }}$ De androg om, at pastor Mørch snarest muligt måtte blive afskediget som sognepræst for Hostrup menighed, idet de klagede over, at Mørch var en trofast og fanatisk dansker, han omgikkes kun ligesindede, især fysikus Ulrich og herredsfoged Lind i Tønder, og virkede kun i dansk interesse. Han havde stor indflydelse på smâfolk i menigheden og påvirkede dem i dansk retning ved udtalelser om, at det danske styre snart ville blive genindført i denne egn, og at danskerne ville vinde sejr over tyskerne. Klagerne henviste til den adresse, Mørch havde varet med til at underskrive i 1861; han udtalte sig stadig ved påkommende lejlighed i samme ånd, skønt han vogtede sig for at komme med sådanne udtalelser over for klagerne eller deres ligesindede. Han 


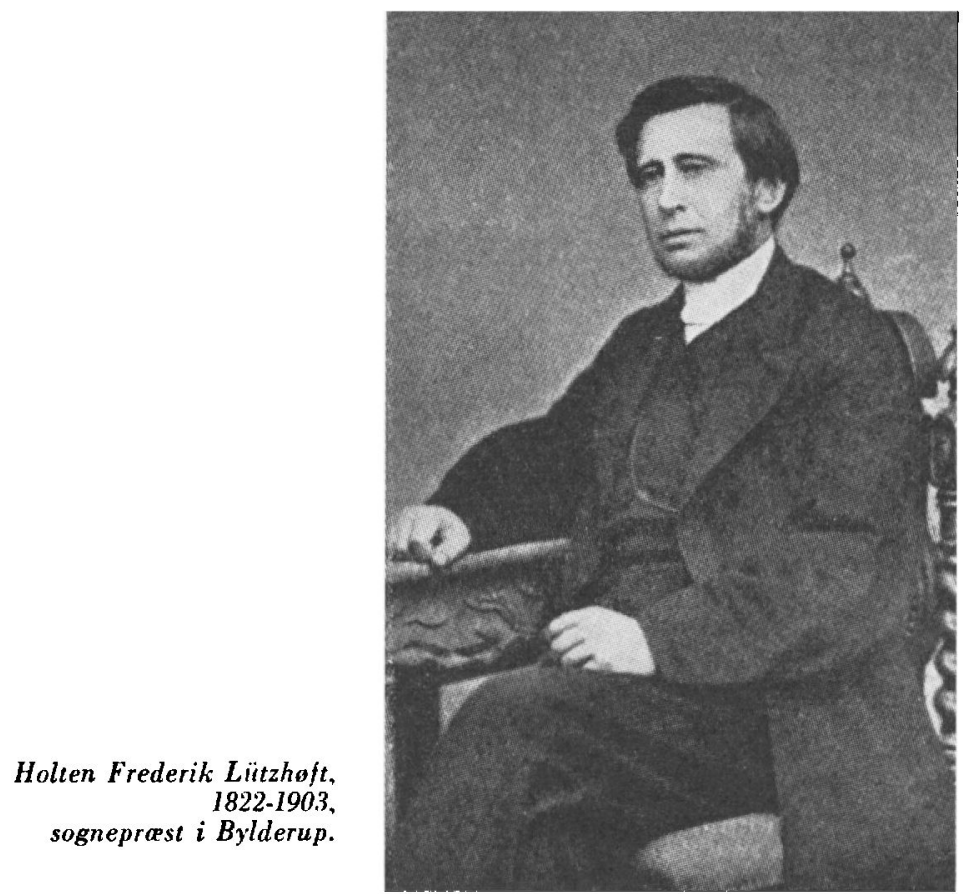

betegnede til stadighed de preussiske og østrigske hærstyrker som "fjendtlige tropper", som navnlig fattighusforstanderen i Hostrup o. a. kunne bevidne. Efter civilkommissærernes vilje skulle det tyske element $i$ hertugdømmet Slesvig beskyttes, og dette kunne efter klagernes mening ikke ske effektivt, så længe en mand som pastor Mørch kunne skræmme småfolk og »udannede medlemmer af menigheden og hans udtalelser ove indflydelse på disse. Klagerne følte sig overbevist om, at der ikke kunne ydes den beskyttelse og sikkerhed for det danske element, som var tilsagt det tyske element, hvis pastor Mørch blev i embedet. Derfor anså de sig for forpligtet til $\mathrm{i}$ den tyske sags interesse og i overensstemmelse med de ønsker, der næredes af de større grundejere $i$ Hostrup sogn, indtrængende at bede om, at kirkevisitatoriet efter evne ville virke for pastor Mørchs afskedigelse.

3. juni mødte Mørch efter tilsigelse for amtmand de Fontenay og provst Valentiner, som var blevet konstitueret i embedet den dag, Kok blev forhørt. ${ }^{\text {sq }}$ Han blev først foreholdt, at det sindelag, 
han havde lagt for dagen $\mathrm{i}$ den erklæring, han havde været med til at underskrive i 1861, ikke var i overensstemmelse med den øverste civiløvrigheds intentioner $\mathrm{m}$. h. t. hertugdømmernes politiske forhold. Mørch svarede, at han ikke mente, han havde sat sig i modsætning til den underkastelseserklæring, han havde afgivet, ved formentlig at have udtalt en anskuelse modsat disse intentioner. Han mente dog ikke, at han i handling havde sat sig i modsætning til landets højeste autoritets intentioner. Hvis imidlertid sådant skulle kunne bevises, var han villig til at afgive en erkl:ering om det. Derefter spurgte kirkevisitatoriet ham ud om den klage, at han forsøgte at skræmme småfolk ved udtalelser om, at det nuværende styre snart ville ophøre, og danskerne atter ville gå af med sejren. Mørch svarede, at det ikke var sandt, at han forsøgte at skræmme småfolk, men han kunne og ville ikke nægte, at han fortalte folk om krigsbegivenhederne, især hvad aviserne meddelte om dem. På spørgsmålet, om han havde betegnet de allierede tropper som sfjendtlige", svarede han benægtende; tværtimod havde han modtaget de indkvarterede officerer og menige venligt og behandlet dem godt. Han mente, at derved kom det ikke videre an på forholdet; det kunne vel være, at han af og til havde betegnet de allierede tropper som « jendtlig armé «, da de jo var kommet ind $i$ landet med våbenmagt, og da alle indkaldte medlemmer af hans menighed befandt sig over for dem i den danske hær; netop på grund af den sidstnæunte omstændighed var det vanskeligt for ham at betegne de allierede tropper anderledes.

I Bylderup var det, som vi har set, vanskeligt at få nogen til at klage over præsten. Sagen med dåbsattesterne kunne ikke bruges til at få denne bort. P. A. Petersen på Cecilielyst, svoger til brødrene Momsen på Vrågård og Store Tønde, samlede i slutningen af april materiale til en klage over Lützhøft. ${ }^{33}$ En fordrukken, tysksindet forpagter, Peter August Clausen i Heds, som var en nær ven af amtmand de Fontenay, opfordrede flere gange i kroerne andre tysksindede til at indgive klage til kirkevisitatoriet over Lützhgft og degnen i Bylderup, Anders Nissen. Den mest ansete hjemmetysker i sognet, Sønnichsen på Hajstrupgård, afslog dog bestandig denne opfordring og svarede, at kunne han ikke gøre noget godt, noget ondt ville han ikke række hånden til, og han syntes, at både 


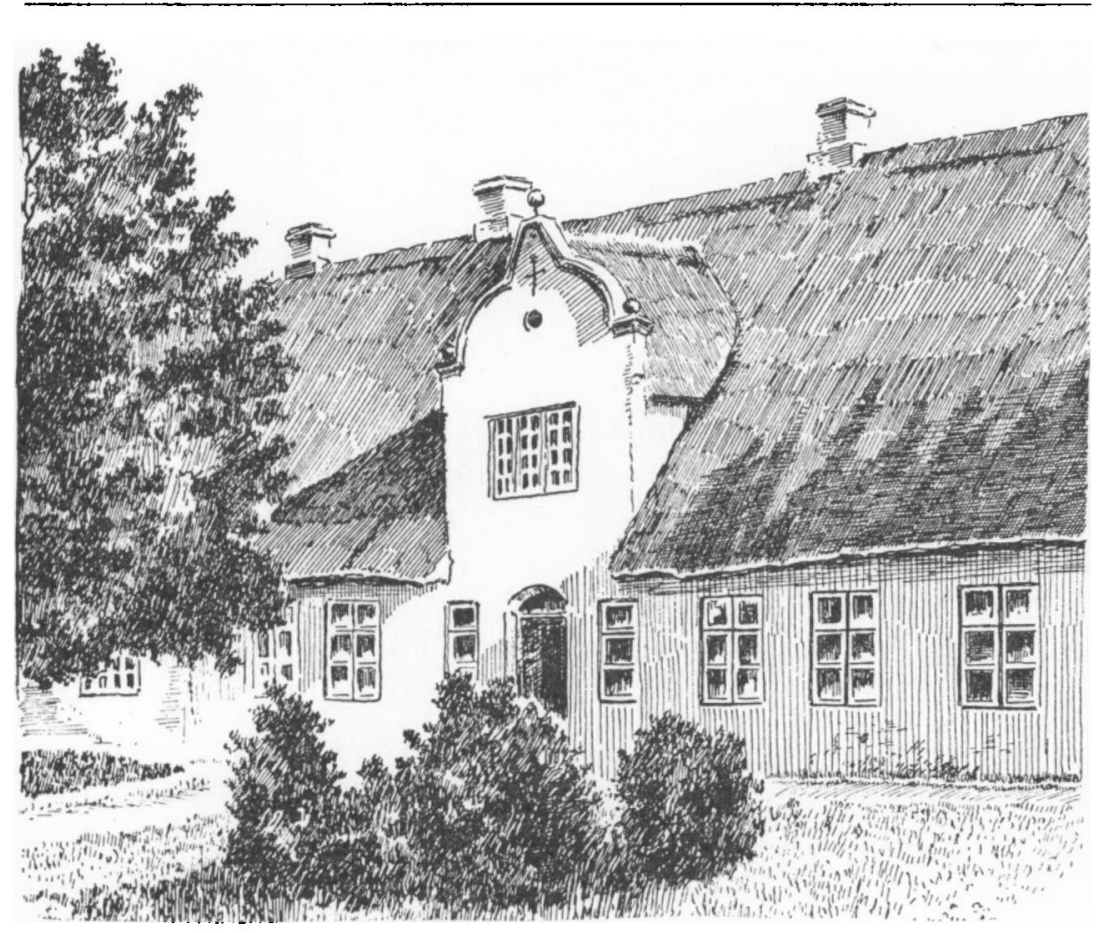

Hostrup prastegård.

(Efter tegning af Hakon Spliid i „Gamle Prastegaarde“" ved H. Zangenberg).

præsten og degnen var sådan, at man kunne være tilfreds med dem."

Clausen fik dog til sidst kromanden i Bredevad, Lorenz Johannsen, overtalt til at være med til at klage over Lützhøft og Nissen. 1. juni mødte de op hos amtmanden ${ }^{35}$ og meddelte, at Lützhøft var en fanatisk dansker og virkede med alle midler, der stod til hans rådighed, for at udbrede sit danske sindelag blandt sognets indbyggere. Han øvede navnlig stor indflydelse på småfolk, men også på nogle af gårdmændene. Han henvendte sig dog ikke til sådanne, af hvem han ikke kunne vente velvillig modtagelse og orenlyd. Hos alle andre søgte han at virke for, at man forblev tro mod den danske konge. De fleste mennesker skænkede hans udtalelser om de politiske forhold tiltro, navnlig når han forsikrede, at det danske styre snart ville vende tilbage og gøre sit herre- 
dømme gældende; derfor var de bange for at gøre noget for at få præsten afskediget. Han havde intim forbindelse med afgjort dansksindede embedsmænd, navnlig med den nu afskedigede pastor Kok i Burkal, pastor Mühlensteth i Bjolderup, pastor Mynster, forhen i Ladelund, og ganske særlig med sin degn, Nissen i Bylderup, som ligeledes var en fanatisk dansker, der sintrigerede" af alle kræfter. Som eksempler på Lützhøfts sfanatisme " anførte klagerne, at han $i$ en begravelsestale for godt 5 âr siden over gårdejer og handelsmand Hans Christian Hansen i Bredevad $^{36}$ havde talt nedsættende om denne "hædersmand " og til sidst sagt til enken: Opdrag nu dine børn sådan, at de ikke går den samme vej, som deres fader er gået «. Desuden var Lützhøft for $\mathbf{8}$ âr siden kommet for sent til en vielse, fordi han havde været til et politisk møde i Møgeltønder, hvori mange andre danske præster deltog.

M. h. t. degnen klagede de pågældende over, at han virkede og agiterede for dansk sindelag, navnlig i skolen, efter hvad børnenes forældre fortalte. Klagerne påstod, at alle »indsigtsfulde " indbyggere, især de større grundejere, var af deres mening. De anså det for påtrængende nødvendigt $i$ den tyske sags og landets interesse, at præsten og degnen hurtigst muligt blev afskediget, og bad amtmanden om at virke herfor efter bedste evne.

Lützhøft blev tilsagt til at møde for kirkevisitatoriet 6 . juni. Dagen før satte han sig i forbindelse med Mørch; af samtalen med ham kunne han slutte sig til, hvad han ville blive spurgt om. Derfor overvejede han mere omhyggeligt end Kok og Mørch, hvad han skulle svare.

6. juni mødte Lützhøft så for kirkevisitatoriet. ${ }^{37}$ Han frabad sig at blive forhørt på tysk, og amtmanden overlod forhøret til provst Valentiner, da han sagdes at kunne bedre dansk end amtmanden (Valentiner havde før Treårskrigen været præst i Rinkenæs og 1849-50 i Tyrstrup). Klagen over Lützhøft blev nu oplæst. Han forlangte, som rimeligt var, at få at vide, hvem der havde klaget over ham, før han svarede på spørgsmålene; da amtmanden ikke ville sige navnene, anså Lützhøft sig ikke for forpligtet til at svare, da han ikke antog, at anonyme udsagn havde magt mod navngiven mand. Amtmanden sagde, at han var Lützhøfts foresatte, hvem han skyldte svar. Da amtmanden lovede Lützhøft 
at sige ham navnene efter forhøret, erklærede han sig villig til at svare. Lützhøft afviste meget bestemt, at han virkede $i$ politisk henseende $\mathrm{i}$ dansk interesse og gjorde sin indflydelse gældende med det formål at udbrede dansk sindelag blandt sit sogns indbyggere eller søgte at skræmme med truslen om, at det danske styre ville vende tilbage; hans gerning var alene kristelig og gejstlig $\mathrm{i}$ overensstemmelse med hans pligter og stilling som præst. Ved Hans Christian Hansens begravelse havde han i sin ligtale ikke ladet sig lede af afdødes tyske sindelag, men udtalt sig om hans livsvandel, fordi den fortjente dadel $\mathbf{i}$ religiøs og moralsk henseende. Tiltalen til enken hentydede ikke til børnenes faders politiske indstilling, men til hans dårlige moralske livsvandel, navnlig hans drukkenskab. Hans fravær ved den omtalte vielse skyldtes ikke et politisk møde i Møgeltønder, men en missionsprædiken sammesteds. Han havde bedt pastor Hogsbro om at foretage vielsen, men denne var ikke kommet. I øvrigt var sagen dengang blevet forhandlet med kirkevisitatoriet og bragt ud af verden. Lützhøft spurgte, om det var passende at fremdrage embedshandlinger fra for 8-9 år siden i undersøgelsen; amtmanden svarede, at disse ting var sveriahrt «. Nu fik Lützhoft forelagt det samme spørgsmål, som også Mørch havde fået, om han var i overensstemmelse med civiløvrighedens intentioner. Lützhaft svarede, at han ikke kendte disse intentioner, og han kendte, såvidt han havde en mening om civiløvrighedens principper, ingen forskel mellem den tidligere regerings og civiløvrighedens principper. Hvis ved civiløvrigheden eller de myndigheder, der var undergivet den, noget måtte blive bestemt $\mathbf{i}$ politisk henseende, som ikke stemte overens med hans samvittighed, så ville han åbent afgive en erklæring derom.

Til sidst mindede Lützhøft amtmanden om hans løfte om at nævne klagernes navne, men han sagde, at det havde han ikke lovet. Provsten holdt med Lützhøft, men han rådede ham for ikke at opfylde sindet med bitter vrede mod disse personer til hellere at opgive sit forlangende. Amtmanden sagde, at Lützhøft beholdt ret til at rejse klage mod disse personer, og at navnene til enhver tid ville blive meddelt ham, hvis han anmodede om det. Lützhøft benyttede sig ikke af det, da han ikke var interesseret $i$ noget sagsanlæg mod de pågældende. 
Ved erklæringer af 8. og 9. juni indstillede kirkevisitatoriet henholdsvis Mørch og Lützhøft til afsked. Ingen af dem ansås for at være i overensstemmelse med civiløvrighedens intentioner, som kirkevisitatoriet opfattede dem, nemlig i slesvigholstensk retning. ${ }^{89} \mathrm{Da}$ det blev bekendt $\mathrm{i}$ de pågældende præsters menigheder, at deres præster havde været $\mathbf{i}$ forhør hos kirkevisitatoriet, henvendte folk fra begge sogne sig til advokat Gjessing i Tønder og fik affattet ansøgninger til civilkommissærerne om at måtte beholde præsterne. ${ }^{30}$ Der skete derefter intet med disse, indtil civilkommissærerne 2. juli udsendte et cirkulære til kirkevisitatorierne, at våbenstilstandens udløb (25. juni) og fjendtlighedernes genoptagelse under væsentlig forandrede omstændigheder gjorde det nødvendigt, at de forsikrede sig om alle de embedsmænds sindelag, som $\mathrm{m}$. h.t. en tidligere aflagt ed hidtil kun betinget havde underkastet sig. Sådanne underkastelseserklæringer kunne de ikke være tjent med; de måtte snarere opfordre enhver, som i sin samvittighed folte sig bundet over for den danske regering, til at løse dette forhold eller frivillig nedlægge sit embede. De bemyndigede kirkevisitatorierne til at bringe den omtalte grundsætning $i$ anvendelse over for de præster og lærere, hos hvem de havde anledning til at betvivle overensstemmelse med samme. Det overlodes til kirkevisitatorierne at bestemme, om de ville foranledige de pågældende til at afgive en erklæring ved forhør til protokol efter forudgående tilsigelse eller ved opfordring til skriftlige udtalelser. ${ }^{* 0}$

I overensstemmelse med dette cirkulære afkrævede kirkevisitatoriet Mørch og Lützhøft erklæringer om, at de i deres samvittighed ikke mere følte sig bundet over for den danske regering. ${ }^{41}$ Mørch nægtede at afgive en sådan erklæring, medens Lützhøft udbad sig nærmere oplysning om, hvad der var at forstå ved udtrykket sden danske regering ". Kirkevisitatoriet opfattede dette som en foreløbig afvisning, som efter dets skøn under de foreliggende omstændigheder måtte anses for væsentlig lig med en ubetinget afvisning. Begge præster blev indstillet til afsked, og 8. august blev de afskediget. Mørch rejste til Vordingborg, hvor han blev lærer ved en realskole, som lededes af hans svoger, cand. theol. Jacob Ørum, indtil han i 1866 blev præst i Øster Starup. Samme år blev han provst, og 1868 blev han præst $i$ 
Sønder Bjært, et af »de 8 sogne». Lützhøft rejste til Kalundborg, hvor hans moder endnu levede. Han måtte vente til 1868 med atter at komme $i$ embede, nemlig som sognepræst til ØrstedDåstrup ved Roskilde.

Da freden i Wien blev sluttet, var Høgsbro den eneste tilbageværende danske præst i Slogs herred. Han fik snart at mærke, at det var vanskeligt at være dansk præst under tysk styre. Generalsuperintendent Godt udsendte 11. november et cirkulære om, at der 2. søndag i advent (4. december) skulle holdes takkefest for freden; aftenen før og om morgenen skulle der ringes med kirkeklokkerne, og der skulle ved gudstjenesten prædikes over Ps. 85,9-14, hvor der bl. a. står: "Retfærd og fred skal kysse hinanden ". Hvor »O store Gud, vi love dig" ikke stod i salmebogen, eller menigheden ikke kunne synge den, skulle der synges " $\mathrm{Nu}$ takker alle Gud", en salme, slesvigholstenerne tidligere på året havde gjort flittig brug af ved deres proklamationer af $\gg$ Dolzigeren " (den augustenborgske prætendent). ${ }^{42}$

Høgsbro følte ingen trang til at holde takkefest for en fred, som bragte hans hjemstavn under tysk herredømme; han lod ikke ringe med kirkeklokken og holdt ingen fredsprædiken, men prædikede som sædvanlig over søndagens evangelium. 30. december kom han i forhør hos provsten ${ }^{43}$ - Valentiner var rejst, og Carstens var endelig blevet provst. Han motiverede sin handling den omtalte søndag med, at han stammede fra en gammel nordslesvigsk familie, var født slesviger (ligesom Carstens), følte sig derfor afgjort som slesviger, men havde altid levet $i$ den anskuelse, at Slesvig var et land, der hørte til Danmark (modsat Carstens). Som følge deraf havde han ikke kunnet have sit hjerte med $i$ en prædiken, som skulle vidne om, at retfærdighed og fred kyssede hinanden, og han havde derfor anset det for det bedste, både for ham selv og menigheden, ikke at holde den prædiken. Han tilføjede, at som forholdene var $i$ hans menighed, ville en fredsprædiken holdt af ham ikke have givet anledning til fred, men snarere til strid i menigheden. Han ville finde det højst beklageligt, hvis han blev tvunget til at forlade sin hjemstavn og sin menighed, som var blevet ham kær i de $\mathbf{1 5}$ år, han havde virket $\mathrm{i}$ den. Han vidste, at han ellers $i$ alle tilfælde, hvor det havde været ham muligt, havde ydet øvrigheden den skyldige lydighed og var også fremdeles villig dertil, hvor han på nogen måde kunne. 
Carstens var ganske vist tysksindet, men ingen fanatiker ${ }^{44}$ han sendte forhørsreferatet til civilkommissærerne med en skrivelse, hvor Høgsbro omtaltes velvilligt. 18, januar 1865 kom civilkommissærernes svar; ${ }^{45}$ det gik ud på, at under hensyn til det gode vidnesbyrd, kirkevisitatoriet havde meddelt Høgsbro, ville de for denne gang ikke lade hans ulydighed mod hans foresatte øvrigheds bestemte anordninger få videre følger, dog i forventning om, at han i fremtiden villigt rettede sig efter hans foresatte øvrigheds bestemmelser. Hvis han skulle føle sig ude af stand til dette, nærede de den tillid til hans samvillighedsfuldhed, at han $i$ så fald nedlagde sit embede.

Et par år efter indtrådte den situation, at Høgsbro ikke fandt det foreneligt med sin samvittighed at rette sig efter en af den tyske ovrigheds bestemmelser. I januar 1867 bestemte myndighederne, at der fra 4 . søndag efter hellig tre konger (27. januar) i de sønderjyske kirker skulle bedes for kongen af Preussen og hans hus. Høgsbro nægtede at gøre det; som følge deraf blev han suspenderet 9. februar og afskediget 20 . maj. Før han rejste fra Højst, forærede de dansksindede i sognet (de var i afgjort flertal ved begge valg i 1867) ham et smukt guldur med kæde til $100 \mathrm{rdl}^{46}$ Han flyttede til Ribe, hvor han boede, til han i 1868 blev præst i Farup efter Th. Kühnel, kendt som forfatter til »Visen om § 5 «. Senere blev han præst i Bjerreby på Tåsinge.

Høgsbro var den første danske præst, som kom til Slogs herred efter treårskrigen; han blev også den sidste danske præst i dette herred før genforeningen. Fra 1867 sad der ligesom før 1850 tyske præster $i$ alle sognene her. Først da i 1920 retten for en gangs skyld sejrede over magten, blev denne unaturlige tilstand forandret.

\section{NOTER OG HENVISNINGER}

1. Vilh. Milthers: Sofus Hegsbros Slægt s. 25.

2. I Hof- og Statskalenderen 1860 kaldes han endnu Hoxbroe, i 1861 Hogsbro.

3. Lützhøft kalder ham Sønderjyske Årbøger 1936 s. 289 sen almenagtet Mand .

4. K. M. Hermansen: Skodborg Sogn s. 171.

5. Om ham se Dansk biografisk Leksikon XIII 102 f. samt Sønderjysk Månedsskrift V 161-65 og Grohshennig og Hauch-Fausbøll: Danmarks Præstehistorie 1884-1911 I 519 ff. 
6. Det er altså ikke rigtigt, når det i Dansk biografisk Leksikon og andetsteds meddeles, at han forst efter krigen 1864 ændrede sit slægtsnavn til Kok.

7. Om ham se Grohshennig og Hauch-Fausbøll anf. værk II $421 \mathrm{f}$. Hans optegnelser fra Bylderup er trykt i Ribe Stifts Arbog 1950 s. 52-59, hans dagbog fra 1864 i uddrag Sonderjyske Årbøger 1936 s. 263-97 og beretning om hans fordrivelse Sønderjysk Månedsskrift 1950 s. 102-12.

8. Dette kan ses af, at i 1864120 af 135 stemmeberettigede ved præstevalg onskede at beholde ham som præst i Bylderup, jfr. anm. 39.

9. Om ham se Grohshennig og Hauch-Fausboll anf. værk I 71.

10. Torninglen provstis journal 1849/150, jfr. sammes kopibog 1845-68 fol. 136 (landsarkivet $i$ Åbenrå).

11. Skrivelse af 5 . august 1849 fra provst Matzen til bispekontoret $i$ Ribe (anforte kopibog fol. 136), jfr. Hjelholt: Sonderjylland under Treårskrigen II 35.

12. Anforte journal for Torninglen provsti $1849 / 222$.

13. Om dette made se Sønderjyllands Historie IV $489 \mathrm{f}$.

14. If jysk Månedsskrift 1950 s. $154 \mathrm{f}$.).

15. Sonderjyske Ärbøger 1936 s. 289 f.

16. Tonder kirkevisitatoriums journal $1864 / 318$ (landsarkivet i Abenrå).

17. Koncept $i$ Tonder kirkevisitatoriums arkiv. Kirkesager vedrarende enkelte sogne, Burkal 1593-1879 (landsarkivet i Ảbenri̊).

18. Tønder kirkevisitatoriums journal $1864 / 311$.

19. Om ham se Jens Lampe: Tonder seminarie-stat $s .60$.

20. Sønderjyske Årbøger 1936 s. 280 (i anm. 1 sammesteds er han blevet forvekslet med sin broder på Store Tonde).

21. Koncept til forhørsprotokollen i pakken næunt $i$ anm. 17. Beretning om forhøret $i$ brev af 14 . april 1864 fra fysikus Ulrich til provst Hjort (Sønderjyske Årbøger 1929 s. 215 f.), jfr. Lützhoft Sønderjyske Årbøger 1936 s. 294.

22. Sønderjyske Arbøger 1936 s. 294.

23. Underkastelseserklæringens ordlyd er gengivet af Lützhoft Sonderjyske Årbøger 1936 s. 277.

24. Den er omtalt i Ulrichs brev til Hjort (Sonderjyske Årboger 1929 s. 216).

25. Sonderjyske Arboger 1936 s. 294.

26. Sonderjyllands Historie V 71.

27. Grohshennig og Hauch-Fausbøll anf. værk I $520 \mathrm{f}$.

28. Sønderjyske Årbøger 1936 s. 296 f.

29. Trykt Sønderjyske Arboger 1936 s. 297. Erklæringen findes i Tonder kirkevisitatoriums arkiv, Kirkesager vedrorende enkelte sogne, Bylderup 1732-1876 (landsarkivet i Ãbenrå).

30. Koncept $i$ pakken nævnt $i$ foregående anm.

31. Koncept $\mathrm{i}$ Tønder kirkevisitatoriums arkiv, Kirkesager vedrorende enkelte sogne, Hostrup 1730-1878 (landsarkivet i Åbenrå).

32. Koncept til forhørsprotokollen i samme pakke, jfr. Sonderjyske Årbøger 1929 s. 217 (efter brev af 3.-4. juni 1864 fra Ulrich til Hjort).

33. Sonderjyske Arbøger 1936 s. 297. 
34. Sonderjysk Månedsskrift $1950 \mathrm{~s} .105 \mathrm{f}$.

35. Koncept i pakken næunt i anm. 29 og 30.

36. Dod 17. juni 1858 , begravet 21. juni samme år.

37. Koncept til forhørsprotokollen i ovennæunte pakke, jfr. Lützhøfts beretning om forhøret Sønderjysk Månedsskrift $1950 \mathrm{~s} .106 \mathrm{ff}$.

38. Kirkevisitatoriet havde $i$ en rundskrivelse til præsterne $i$ Tonder amt 12. maj 1864 defineret disse intentioner som genoprettelsen af den ret til at nyde de fortrin og frugter, som "fra urgammel tid « var tilfaldet hertugdømmet Slesvig i dets forbindelse med Holsten ved den tyske dannelses sível som det tyske kirke- og skolevæsens indflydelse (Meddelelser om Begivenhederne i Slesvig siden den preussisk-ostrigske Invasion - Den 1ste November 1864 - s. 146).

39. Ansogningen fra Hostrup sogn findes $i$ pakken nævnt $i$ anm. 31 og 32. Den fik 124 underskrifter (af 144 stemmeberettigede ved prastevalg). Om ansøgningen fra Bylderup sogn, der, som nævnt i anm. 8, blev underskrevet af 120 af 135 stemmeberettigede. se Sonderjysk Månedsskrift 1950 s. 108.

40. Cirkulæret trykt i uddrag Meddelelser osv. s. 148.

41. Koncept til kirkevisitatoriets skrivelse til civilkommissærerne af 24. juli 1864 om afskedigelse af præsterne Mørch og Lützhøft i ovennævnte pakke kirkesager vedrorende Hostrup sogn i Tonder kirkevisitatoriums arkiv i landsarkivet i Ảben rå.

42. Meddelelser om Begivenhederne i Slesvig siden den preussiskosterrigske Invasion (Januar 1865) s. $93 \mathrm{ff}$.

43. Tonder kirkevisitatoriums arkiv, Kirkesager vedrorende enkelte sogne, Hojst 1702-1879 (landsarkivet i Ảbenråi.

44. Nyholm: Nationale og religiose brydninger i Tonder pi sprogreskripternes tid s. 19.

45. Findes i pakken nævnt i anm. 43.

46. Vilh. Milthers anf, værk s. 25. Ved valget til den nordtyske rigsdag i februar 1867 blev der i Hojst sogn afgivet 56 danske og 23 tyske stemmer. 